Case Report

\title{
Familial Adenomatous Polyposis Manifesting as Lactococcus Endocarditis: A Case Report and Review of the Association of Lactococcus with Underlying Gastrointestinal Disease
}

\author{
Taylor C. Bazemore, ${ }^{1}$ Stacey A. Maskarinec, ${ }^{2}$ Kahli Zietlow, ${ }^{1}$ \\ Edward F. Hendershot, ${ }^{2}$ and John R. Perfect ${ }^{2}$ \\ ${ }^{1}$ Department of Internal Medicine, Duke University Hospital, Durham, NC, USA \\ ${ }^{2}$ Division of Infectious Diseases, Department of Internal Medicine, Duke University Hospital, Durham, NC, USA \\ Correspondence should be addressed to John R. Perfect; john.perfect@dm.duke.edu
}

Received 18 June 2016; Accepted 19 July 2016

Academic Editor: Antonella Marangoni

Copyright (C) 2016 Taylor C. Bazemore et al. This is an open access article distributed under the Creative Commons Attribution License, which permits unrestricted use, distribution, and reproduction in any medium, provided the original work is properly cited.

\begin{abstract}
A 45-year-old male with a prosthetic aortic valve presented to the hospital with several months of generalized malaise. On admission, he was noted to have anemia of unclear etiology and subsequently became febrile with multiple blood cultures growing Lactococcus garvieae. Inpatient workup was concerning for infectious endocarditis (IE) secondary to Lactococcus. The patient was discharged home with appropriate antimicrobial therapy; however, he was readmitted for persistent, symptomatic anemia and underwent colonoscopy, which revealed innumerable colonic polyps consistent with Familial Adenomatous Polyposis (FAP) that was later confirmed with genetic testing. Surveillance computed tomography (CT) imaging of the aortic repair later demonstrated valve dehiscence with surrounding fluid collection; he underwent redo surgery and was found to have destruction of the aortic annulus and a large pseudoaneurysm. Histopathology of the valve prosthesis confirmed IE. It is suspected that the patient developed Lactococcus IE from enteric translocation. Review of the literature provides several reports of Lactococcus infections in association with underlying gastrointestinal disease, including colorectal cancer. Given this association, we raise the question of whether the diagnosis of Lactococcus IE should evoke suspicion and encourage evaluation for gastrointestinal pathology, as occurs with Streptococcus bovis.
\end{abstract}

\section{Introduction}

The Lactococcus genus is a gram-positive, catalase-positive, anaerobic coccus that produces lactic acid from the fermentation of carbohydrates. It was formerly included in the Streptococcus genus and is often misidentified as Enterococcus. There are now eight recognized Lactococcus species, with the two most common being Lactococcus garvieae and Lactococcus lactis. In general, these organisms are known to be sensitive to most $\beta$-lactam antibiotics and aminoglycosides [1].

Although typically considered an opportunistic pathogen, Lactococcus has been responsible for systemic human infections with varied manifestations including bacteremia, peritonitis, liver abscess, endocarditis, and osteomyelitis [2].
Furthermore, infective endocarditis (IE) stemming from Lactococcus bacteremia is a particularly rare clinical entity, but it has been reported in several case studies that emphasize patients with prosthetic heart valves [3-6]. Of the reported cases of Lactococcus infection, there is a frequent association with consumption of raw fish or dairy products [7]. In particular, L. garvieae has been more broadly associated with fish and dairy consumption, with transmission also reported via contaminated water; conversely, L. lactis is associated primarily with dairy products $[8,9]$. Importantly, in many of the reported cases, these patients had underlying gastrointestinal (GI) disease, suggesting a portal of entry $[1,5,7,10-13]$. While not normally part of the GI microbiome, Lactococcus has been isolated from the intestines of humans $[1,10]$. 


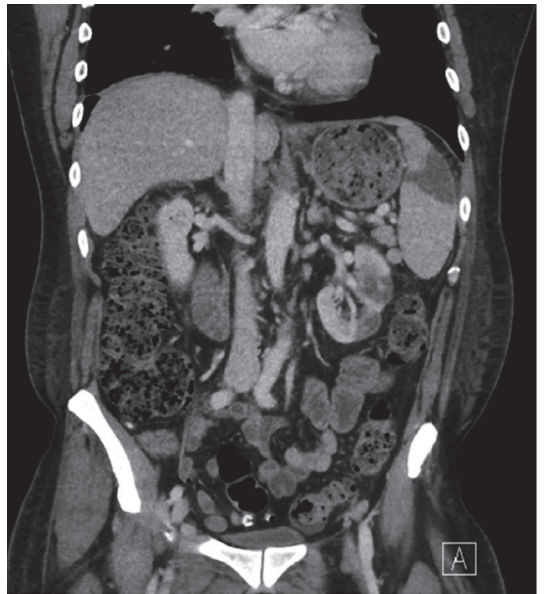

Figure 1: Computed tomography scan of chest/abdomen/pelvis demonstrating splenic and left renal infarction.

\section{Case Presentation}

A 45-year-old male was admitted for further evaluation of presumed symptomatic anemia. The patient had a past medical history significant for treatment-naïve hepatitis $\mathrm{C}$, remote polysubstance abuse, and Bentall repair of an aortic root aneurysm approximately 18 months prior to presentation. He endorsed two months of generalized malaise and subjective, generalized weakness without other localizing symptoms. The patient denied consumption of raw fish or fermented milk products. Upon presentation, he was febrile to $39.5^{\circ} \mathrm{C}$ with other vital signs within normal limits. Physical exam was remarkable for a IV/VI systolic murmur at the left upper sternal border. Admission lab results were significant for white blood cell count of $12.9 \times 10^{9} / \mathrm{L}\left(3.2-9.8 \times 10^{9} / \mathrm{L}\right.$ g/dL), hemoglobin of $10.2 \mathrm{~g} / \mathrm{dL}(13.7-17.3 \mathrm{~g} / \mathrm{dL})$, erythrocyte sedimentation rate of $100 \mathrm{~mm} / \mathrm{hr}(0-15 \mathrm{~mm} / \mathrm{hr})$, and C-reactive protein of $5.03 \mathrm{mg} / \mathrm{dL}(\leq 0.6 \mathrm{mg} / \mathrm{dL})$. Blood cultures were collected, and the patient was started on empiric antibiotic therapy with vancomycin and piperacillin-tazobactam due to concern for prosthetic valve IE.

Admission blood cultures grew L. garvieae and remained positive on repeated cultures for the following three days. This pathogen was identified by matrix-assisted laser desorption/ionized time of flight (MALDI-TOF) mass spectrometry (bioMérieux Vitek MS, Knowledge Base 2.0X). Both transthoracic and transesophageal echocardiograms demonstrated thickened valvular leaflets and periaortic thickening but revealed no vegetation. CT of the chest, abdomen, and pelvis demonstrated splenic and left renal infarcts concerning for embolic phenomena (Figure 1).

On hospital day 1 , the patient's hemoglobin dropped from $10.2 \mathrm{~g} / \mathrm{dL}$ to $8.3 \mathrm{~g} / \mathrm{dL}$, and he continued to have persistent and worsening anemia over the course of his hospitalization. He had no signs of GI bleeding on rectal examination, and laboratory workup was consistent with anemia of chronic disease. An endoscopy was performed that was negative for any signs of bleeding but did reveal multiple duodenal polyps. A polyp was biopsied with pathology demonstrating

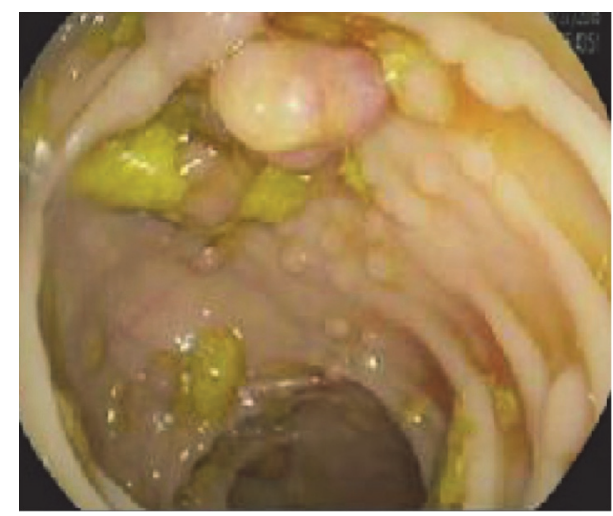

Figure 2: Colonoscopy demonstrating diffuse intestinal polyposis.

tubular adenoma. Ultrasound of the abdomen revealed a morphologically cirrhotic liver.

The patient was diagnosed with possible prosthetic valve IE secondary to L. garvieae bacteremia, although he met only four of the minor Duke Criteria for endocarditis: predisposing heart valve, temperature $>38^{\circ} \mathrm{C}$, persistently positive blood cultures, and embolic phenomena that included infarcts of his kidney and spleen [11]. While he did not have direct or echocardiographic evidence of intracardiac infection at the time of diagnosis, the patient's clinical presentation was consistent with prosthetic valve IE, and it was recommended that he receive a six-week course of antibiotic therapy with ceftriaxone and gentamicin based on the minimal inhibitory concentration (MIC) noted on Etest. This regimen was derived from traditional recommendations for the treatment of prosthetic valve IE caused by intermediate resistance viridans group streptococci or Streptococcus bovis [12], although the synergistic effect of gentamycin has been proven to be limited in the treatment of L. garvieae [13]. The patient was only able to complete two of the six weeks of gentamicin therapy due to the development of acute kidney injury.

Nine days following his initial discharge, the patient was readmitted to the hospital after again presenting with signs and symptoms of anemia. A colonoscopy was obtained and revealed innumerable ( 3 to $12 \mathrm{~mm}$ ) polyps throughout the entire colon, concerning for Familial Adenomatous Polyposis (FAP) or a similar polyposis syndrome (Figure 2). Pathology of biopsied polyps demonstrated tubular adenomas and tubulovillous adenomas with high-grade dysplasia but no evidence of invasive carcinoma. Given the extent of his polyposis, the patient was advised to undergo definitive surgical management; he ultimately underwent total colectomy 8 months following his initial presentation. Subsequent genetic testing revealed that the patient was positive for the mutated APC gene thereby confirming the diagnosis of FAP [23].

Following completion of six weeks of antibiotic therapy, the patient underwent surveillance CT imaging that demonstrated partial aortic valve dehiscence and a fluid collection surrounding the aortic valve prosthesis concerning for pseudoaneurysm. Given these findings, the patient was referred for surgical management. Four months following his initial presentation, he underwent repair of the aortic root 
TABLE 1: Review of reported Lactococcus infections in association with underlying gastrointestinal disease.

\begin{tabular}{|c|c|c|c|c|c|c|}
\hline Reference & Age/sex & Type of infection & $\begin{array}{c}\text { Preexisting GI } \\
\text { lesion(s) }\end{array}$ & $\begin{array}{c}\text { Predisposing risk } \\
\text { factors }\end{array}$ & Treatment & Outcome \\
\hline $\begin{array}{l}\text { Antolín et al. } \\
{[14]}\end{array}$ & $79 / \mathrm{F}$ & Liver abscess & Diverticulosis & None reported & $\begin{array}{l}\text { Imipenem- } \\
\text { cilastatin } \\
\quad(5 \mathrm{w})\end{array}$ & $\begin{array}{c}\text { Clinical } \\
\text { improvement }\end{array}$ \\
\hline Chan et al. [15] & $70 / \mathrm{M}$ & $\begin{array}{c}\text { Infectious } \\
\text { spondylodiscitis }\end{array}$ & Gastritis & $\begin{array}{c}\text { Raw fish } \\
\text { consumption }\end{array}$ & Ampicillin (6w) & $\begin{array}{c}\text { Clinical } \\
\text { improvement }\end{array}$ \\
\hline $\begin{array}{l}\text { Fihman et al. } \\
{[16]}\end{array}$ & $86 / \mathrm{F}$ & Prosthetic AV IE & Duodenal ulcer & $\begin{array}{l}\text { Prosthetic AV and } \\
\text { cholecystectomy }\end{array}$ & $\begin{array}{c}\text { Amoxicillin, } \\
\text { gentamicin, }(4 \mathrm{w}) \\
\text { and then } \\
\text { amoxicillin }(3 \mathrm{w})\end{array}$ & $\begin{array}{c}\text { Clinical } \\
\text { improvement }\end{array}$ \\
\hline $\begin{array}{l}\text { Fleming et al. } \\
\text { [3] }\end{array}$ & $68 / \mathrm{M}$ & $\begin{array}{l}\text { Prosthetic AV IE } \\
\text { and native MV IE }\end{array}$ & Colon polyps & $\begin{array}{c}\text { Raw fish } \\
\text { consumption and } \\
\text { prosthetic AV }\end{array}$ & Vancomycin $(6 \mathrm{w})$ & $\begin{array}{c}\text { Clinical } \\
\text { improvement }\end{array}$ \\
\hline Kim et al. [17] & $69 / \mathrm{M}$ & $\begin{array}{l}\text { Acalculous } \\
\text { cholecystitis }\end{array}$ & Gastric ulcer & $\begin{array}{c}\text { Raw fish } \\
\text { consumption, } \\
\text { working as } \\
\text { fisherman, and } \\
\text { alcoholism }\end{array}$ & $\begin{array}{l}\text { Cefminox and then } \\
\text { cefaclor }(8 \mathrm{~d})\end{array}$ & $\begin{array}{c}\text { Clinical } \\
\text { improvement }\end{array}$ \\
\hline $\begin{array}{l}\text { Mofredj et al. } \\
{[18]}\end{array}$ & $68 / \mathrm{F}$ & Liver abscess & Cholangiocarcinoma & $\begin{array}{l}\text { Biliary prosthesis } \\
\text { and steroid use }\end{array}$ & $\begin{array}{l}\text { Amoxicillin, } \\
\text { netilmicin, and } \\
\text { metronidazole } \\
\text { (12 d until death) }\end{array}$ & $\begin{array}{l}\text { Died from GI } \\
\text { hemorrhage }\end{array}$ \\
\hline $\begin{array}{l}\text { Nadrah et al. } \\
{[19]}\end{array}$ & $81 / \mathrm{M}$ & Bacteremia & Diverticulosis & $\begin{array}{c}\text { Prosthetic AV, } \\
\text { prosthetic MV, and } \\
\text { PPM }\end{array}$ & $\begin{array}{c}\text { Piperacillin- } \\
\text { tazobactam, then } \\
\text { ampicillin, and } \\
\text { gentamicin }(6 \mathrm{w})\end{array}$ & $\begin{array}{c}\text { Clinical } \\
\text { improvement }\end{array}$ \\
\hline Ortiz et al. [20] & $77 / \mathrm{F}$ & Native MV/AV IE & Colorectal carcinoma & $\begin{array}{l}\text { Recent colorectal } \\
\text { carcinoma surgery }\end{array}$ & $\begin{array}{l}\text { Ampicillin and } \\
\text { gentamicin }(6 \mathrm{w})\end{array}$ & $\begin{array}{l}\text { Died from heart } \\
\text { failure }\end{array}$ \\
\hline $\begin{array}{l}\text { Rasmussen et al. } \\
{[5]}\end{array}$ & $81 / \mathrm{M}$ & $\begin{array}{l}\text { Prosthetic AV IE } \\
\text { and native MV IE }\end{array}$ & Diverticulosis & Prosthetic AV & $\begin{array}{l}\text { Penicillin and } \\
\text { tobramycin }(3 \mathrm{w})\end{array}$ & $\begin{array}{c}\text { Clinical } \\
\text { improvement }\end{array}$ \\
\hline Vinh et al. [1] & $80 / \mathrm{M}$ & Native AV IE & Colon polyp & None reported & Ampicillin (6w) & $\begin{array}{c}\text { Clinical } \\
\text { improvement }\end{array}$ \\
\hline Wang et al. [21] & $72 / \mathrm{M}$ & MV IE & Gastric ulcer & $\begin{array}{c}\text { Raw fish } \\
\text { consumption }\end{array}$ & $\begin{array}{l}\text { Penicillin }(4 \mathrm{w}) \text { and } \\
\text { gentamicin }(2 \mathrm{w})\end{array}$ & $\begin{array}{c}\text { Clinical } \\
\text { improvement }\end{array}$ \\
\hline Wang et al. [21] & $56 / \mathrm{F}$ & Bacteremia & $\begin{array}{l}\text { Small bowel } \\
\text { diverticulosis }\end{array}$ & None reported & $\begin{array}{l}\text { Cefazolin, } \\
\text { gentamicin }(2 \mathrm{~d}), \\
\text { and then } \\
\text { cotrimoxazole }(5 \mathrm{~d})\end{array}$ & $\begin{array}{c}\text { Clinical } \\
\text { improvement }\end{array}$ \\
\hline Wang et al. [21] & $47 / \mathrm{M}$ & Peritonitis & Intestinal perforation & $\begin{array}{c}\text { Raw fish } \\
\text { consumption }\end{array}$ & $\begin{array}{l}\text { Piperacillin and } \\
\text { amikacin }(1 \mathrm{w})\end{array}$ & $\begin{array}{c}\text { Clinical } \\
\text { improvement }\end{array}$ \\
\hline Zuily et al. [22] & $64 / \mathrm{F}$ & Prosthetic MV IE & Colon polyps & $\begin{array}{l}\text { Fish consumption, } \\
\text { prosthetic MV, } \\
\text { PPM, and cirrhosis }\end{array}$ & $\begin{array}{l}\text { Amoxicillin and } \\
\text { gentamicin }(6 \mathrm{w})\end{array}$ & $\begin{array}{c}\text { Clinical } \\
\text { improvement }\end{array}$ \\
\hline
\end{tabular}

$\mathrm{AV}=$ aortic valve, $\mathrm{MV}=$ mitral valve, $\mathrm{TV}=$ tricuspid valve, $\mathrm{IE}=$ infective endocarditis, $\mathrm{PPM}=$ permanent pacemaker, $\mathrm{w}=$ week, $\mathrm{d}=\mathrm{day}, \mathrm{F}=$ female, and $\mathrm{M}=$ male.

with replacement of the bioprosthetic valve. Intraoperatively, there was near-complete dehiscence of the valve conduit from the annulus and significant destruction of the aortic annulus with a large pseudoaneurysm. Cultures of the valve were negative for bacterial growth and pathology showed chronic inflammatory changes without any signs of residual infection. These operative findings are nonetheless indicative of a prior intracardiac infection, satisfying the remainder of the Duke
Criteria and thus confirming his diagnosis of prosthetic valve IE secondary to L. garvieae bacteremia.

The patient tolerated the surgery and remained stable through the postoperative period. He was discharged home on postoperative day 5 . Following discharge, the patient was free from any signs or symptoms of persistent or relapsed infection. He underwent surveillance cardiac magnetic resonance imaging (MRI) at 14 months following surgery which 
showed no abnormalities of the repaired aortic root or aortic valve prosthesis.

\section{Discussion}

The patient in this reported case presented with anemia of unclear etiology and was ultimately found to have diffuse intestinal polyposis concerning for FAP. Genetic testing revealed that the patient was heterozygous for a pathogenic variant in the APC gene, consistent with FAP or attenuated FAP. Revelation of the patient's extensive GI pathology occurred in conjunction with his diagnosis of L. garvieae endocarditis. This patient lacked the traditional risk factors of raw fish or dairy consumption that have been reported to predispose patients to infection with Lactococcus. It is suspected that bacterial translocation associated with his colonic disease likely facilitated this infection. Notably, given the patient's history of polysubstance abuse, it is important to consider intravenous (IV) drug use as an alternative mode of bacterial introduction; however, the patient denied any current or prior use of IV drugs. Furthermore, Lactococcus IE has not been described to occur in association with IV drug use.

Given the development of a pseudoaneurysm in the setting of the patient's bacteremia, it is important to consider mycotic aneurysm as the primary nidus of infection, as Lactococcus IE has been reported to occur in the association with mycotic aneurysms [5]. However, the operative findings and pathological analysis of the pseudoaneurysmal tissue did not show any signs of infection consistent with mycotic aneurysm, although surgery was performed following the completion of antibiotic therapy. The patient's concomitant hepatitis $\mathrm{C}$ cirrhosis may have acted as an additional risk factor for the development of IE, considering the increased risk of bacteremia in patients with cirrhosis secondary to the compromise in host defense [24, 25]. Zuily and colleagues similarly describe a patient with Lactococcus IE in the setting of hepatitis C cirrhosis [22].

Several prior clinical reports describe Lactococcus infections in association with underlying GI diseases, including cases of patients with colonic polyps or colorectal cancer, as well as patients with nonneoplastic lesions such as diverticular and ulcerative disease; we have reviewed the literature for cases of Lactococcus infections in association with GI diseases (Table 1). Reports include patients who are mostly of middleto-advanced age with a variety of GI pathologies, but to date, this is the first case of Lactococcus infection that has been reported in association with FAP or other diffuse GI polyposis syndromes.

In this case, the diagnosis of $L$. garvieae prosthetic valve IE proved to be a harbinger of a serious underlying disease. Considering his significant polyp burden and concomitant symptomatic anemia, it is possible that a timely colonoscopy would have otherwise revealed this polyposis syndrome. However, in patients with less severe disease, the diagnosis of Lactococcus bacteremia and/or endocarditis may be an early indication of undiagnosed GI pathology, including colonic malignancy. Therefore, given our findings and other reports of Lactococcus infections associated with GI lesions including colorectal cancer, we propose that the diagnosis of Lactococcus endocarditis should evoke suspicion and encourage evaluation for GI pathology as is recommended with Streptococcus bovis IE [26]. By establishing the association between this infection and the potential risk of underlying GI lesions including colorectal carcinoma, expedient colonoscopy in patients with Lactococcus endocarditis may allow for earlier diagnosis and treatment of cancer in patients with occult disease.

\section{Competing Interests}

Stacey A. Maskarinec has received research support from the National Institutes of Health (no. 5T32-AI052080-12). John R. Perfect reports grants from Astellas, Merck, and Scynexis, has participated in research supported by Pfizer, and has served as consultant for F2G. Taylor C. Bazemore, Kahli Zietlow, and Edward F. Hendershot have no conflict of interests.

\section{References}

[1] D. C. Vinh, K. A. Nichol, F. Rand, and J. M. Embil, "Native-valve bacterial endocarditis caused by Lactococcus garvieae," Diagnostic Microbiology and Infectious Disease, vol. 56, no. 1, pp. 9194, 2006.

[2] T. F. Hirakawa, F. A. A. da Costa, M. C. Vilela, M. Rigon, H. Abensur, and M. R. E. de Araújo, "Lactococcus garvieae endocarditis: first case report in Latin America," Arquivos Brasileiros de Cardiologia, vol. 97, no. 5, pp. e108-e110, 2011.

[3] H. Fleming, S. V. Fowler, L. Nguyen, and D. M. Hofinger, "Lactococcus garvieae multi-valve infective endocarditis in a traveler returning from South Korea," Travel Medicine and Infectious Disease, vol. 10, no. 2, pp. 101-104, 2012.

[4] V. Heras Cañas, M. D. Pérez Ramirez, F. Bermudez Jiménez et al., "Lactococcus garvieae endocarditis in a native valve identified by MALDI-TOF MS and PCR-based 16s rRNA in Spain: a case report," New Microbes and New Infections, vol. 5, pp. 13-15, 2015.

[5] M. Rasmussen, J. Björk Werner, M. Dolk, and B. Christensson, "Lactococcus garvieae endocarditis presenting with subdural haematoma," BMC Cardiovascular Disorders, vol. 14, article 13, 2014.

[6] M. Wilbring, K. Alexiou, H. Reichenspurner, K. Matschke, and S. M. Tugtekin, "Lactococcus garvieae causing zoonotic prosthetic valve endocarditis," Clinical Research in Cardiology, vol. 100, no. 6, pp. 545-546, 2011.

[7] G. Russo, M. Iannetta, A. D’Abramo et al., "Lactococcus garvieae endocarditis in a patient with colonic diverticulosis: first case report in Italy and review of the literature," New Microbiologica, vol. 35, no. 4, pp. 495-501, 2012.

[8] M. Eyngor, A. Zlotkin, C. Ghittino et al., "Clonality and diversity of the fish pathogen Lactococcus garvieae in Mediterranean countries," Applied and Environmental Microbiology, vol. 70, no. 9, pp. 5132-5137, 2004.

[9] C. Ferrario, G. Ricci, C. Milani et al., "Lactococcus garvieae: where is it from? A first approach to explore the evolutionary history of this emerging pathogen," PLoS ONE, vol. 8, no. 12, Article ID e84796, 2013.

[10] C. Rostagno, P. Pecile, and P. L. Stefàno, "Early Lactococcus lactis endocarditis after mitral valve repair: a case report and literature review," Infection, vol. 41, no. 4, pp. 897-899, 2013. 
[11] J. S. Li, D. J. Sexton, N. Mick et al., "Proposed modifications to the Duke criteria for the diagnosis of infective endocarditis," Clinical Infectious Diseases, vol. 30, no. 4, pp. 633-638, 2000.

[12] L. M. Baddour, W. R. Wilson, A. S. Bayer et al., "Infective endocarditis in adults: diagnosis, antimicrobial therapy, and management of complications: a scientific statement for healthcare professionals from the American Heart Association," Circulation, vol. 132, no. 15, pp. 1435-1486, 2015.

[13] M. Rasmussen, T. Sunnerhagen, and P. Hammarlund, "A case of suspected infective endocarditis with Lactococcus garvieae: lack of in vitro synergy between ampicillin and gentamicin," JMM Case Reports, vol. 2, no. 1, 2015.

[14] J. Antolín, R. Cigüenza, I. Salueña, E. Vázquez, J. Hernández, and D. Espinós, "Liver abscess caused by Lactococcus lactis cremoris: a new pathogen," Scandinavian Journal of Infectious Diseases, vol. 36, no. 6-7, pp. 490-491, 2004.

[15] J. F. W. Chan, P. C. Y. Woo, J. L. L. Teng et al., "Primary infective spondylodiscitis caused by Lactococcus garvieae and a review of human L. garvieae infections," Infection, vol. 39, no. 3, pp. 259264, 2011.

[16] V. Fihman, L. Raskine, Z. Barrou et al., "Lactococcus garvieae endocarditis: identification by $16 \mathrm{~S}$ rRNA and sodA sequence analysis," Journal of Infection, vol. 52, no. 1, pp. e3-e6, 2006.

[17] J. H. Kim, J. Go, C. R. Cho, J. I. Kim, M. S. Lee, and S. C. Park, "First report of human acute acalculous cholecystitis caused by the fish pathogen lactococcus garvieae," Journal of Clinical Microbiology, vol. 51, no. 2, pp. 712-714, 2013.

[18] A. Mofredj, D. Baraka, J. F. Cadranel, P. LeMaitre, G. Kloeti, and J. L. Dumont, "Lactococcus garvieae septicemia with liver abscess in an immunosuppressed patient," American Journal of Medicine, vol. 109, no. 6, pp. 513-514, 2000.

[19] K. Nadrah, T. Cerar, L. Papst et al., "Lactococcus garvieae septicaemia in a patient with artificial heart valves," Wiener Klinische Wochenschrift, vol. 123, no. 21-22, pp. 677-679, 2011.

[20] C. Ortiz, J. López, E. Del Amo, T. Sevilla, P. E. García, and J. A. San Román, "Lactococcus garvieae infective endocarditis: report of 2 cases and review of the literature," Revista Espanola de Cardiologia, vol. 67, no. 9, pp. 776-778, 2014.

[21] C. Y. Wang, H. S. Shie, S. C. Chen et al., "Lactococcus garvieae infections in humans: possible association with aquaculture outbreaks," International Journal of Clinical Practice, vol. 61, no. 1, pp. 68-73, 2007.

[22] S. Zuily, Z. Mami, and C. Meune, "Lactococcus garvieae endocarditis," Archives of Cardiovascular Diseases, vol. 104, no. 2, pp. 138-139, 2011.

[23] M. L. Leoz, S. Carballal, L. Moreira, T. Ocaña, and F. Balaguer, "The genetic basis of familial adenomatous polyposis and its implications for clinical practice and risk management," The Application of Clinical Genetics, vol. 8, article 95, 2015.

[24] C.-H. Kuo, C.-S. Changchien, C.-Y. Yang, I.-S. Sheen, and Y.-F. Liaw, "Bacteremia in patients with cirrhosis of the liver," Liver, vol. 11, no. 6, pp. 334-339, 1991.

[25] A. M. Thulstrup, H. T. Sørensen, H. C. Schønheyder, J. K. Møller, and U. Tage-Jensen, "Population-based study of the risk and short-term prognosis for bacteremia in patients with liver cirrhosis," Clinical Infectious Diseases, vol. 31, no. 6, pp. 13571361, 2000.

[26] N. J. Beeching, T. I. Christmas, R. B. Ellis-Pegler, and G. I. Nicholson, "Streptococcus bovis bacteraemia requires rigorous exclusion of colonic neoplasia and endocarditis," Quarterly Journal of Medicine, vol. 56, no. 220, pp. 439-450, 1985. 


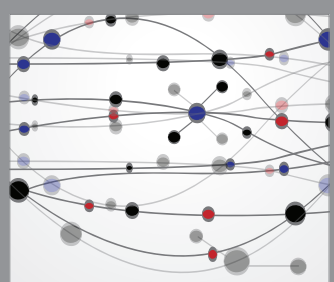

The Scientific World Journal
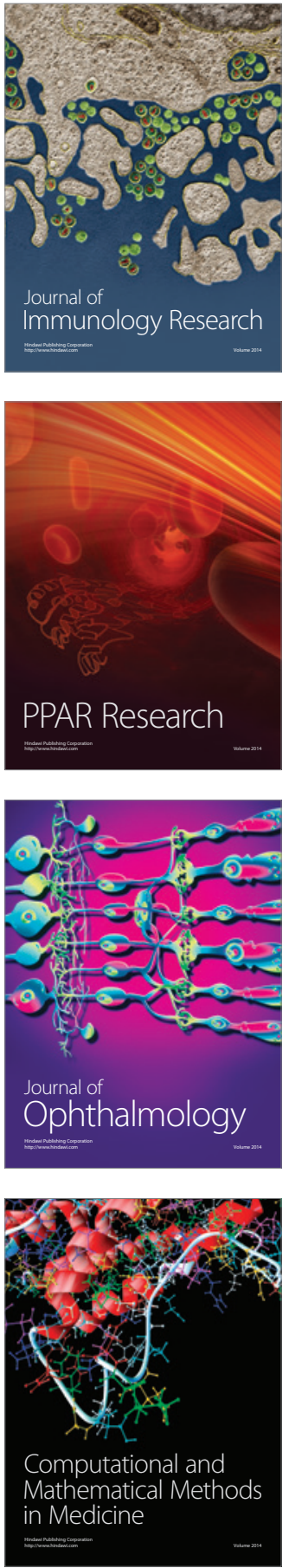

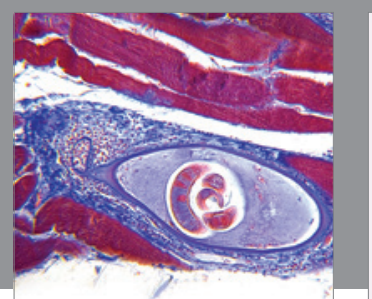

Gastroenterology Research and Practice

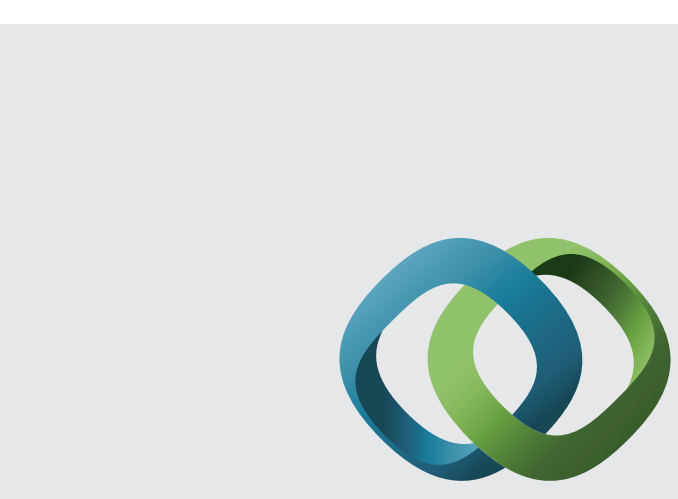

\section{Hindawi}

Submit your manuscripts at

http://www.hindawi.com
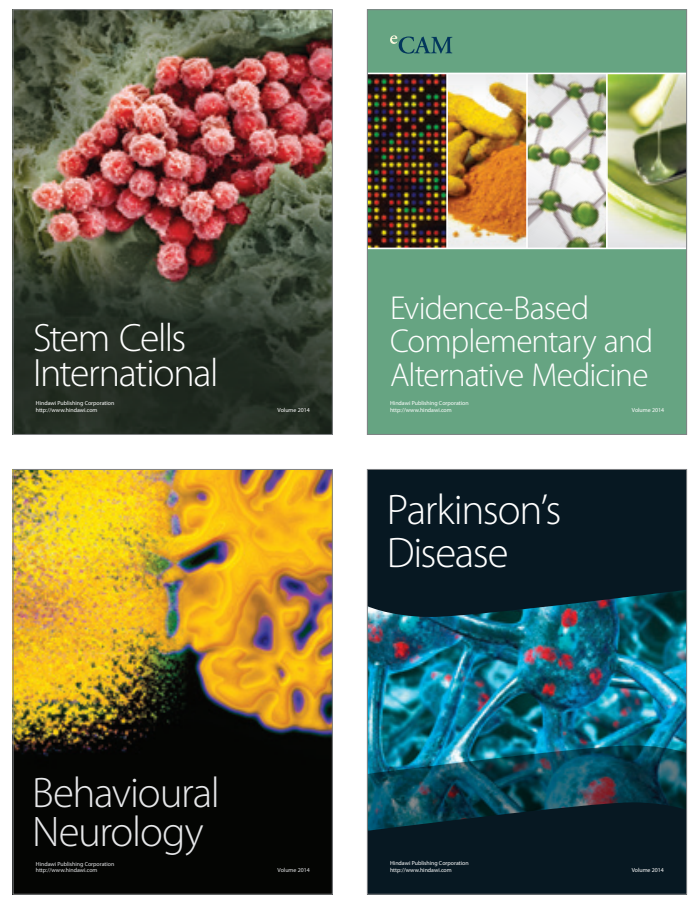
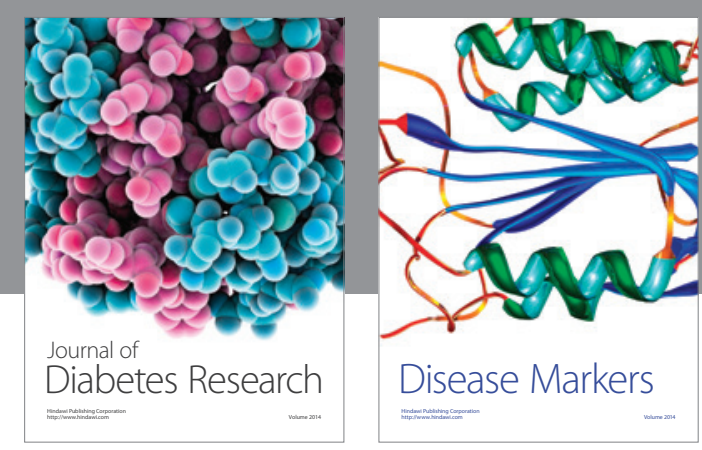

Disease Markers
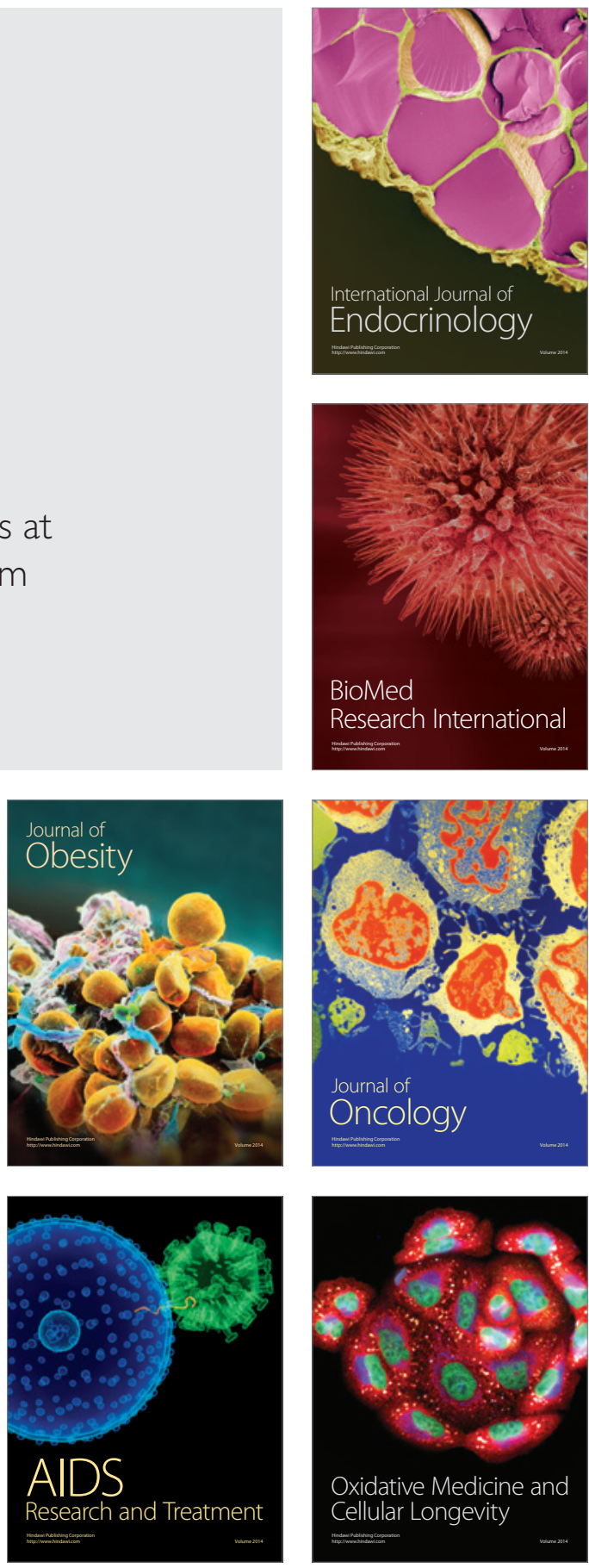